\title{
WORKS COUNCILS AND ENVIRONMENTAL INVESTMENT: THEORY AND EVIDENCE FROM GERMAN PANEL DATA
}

\author{
JAN ERIK ASKILDSEN \\ UWE JIRJAHN \\ STEPHEN C. SMITH
}

CESIFO WORKING PAPER NO. 785

CATEGORY 4: LABOUR MARKETS

OCTOBER 2002

- from the CESifo website: www.CESifo.de 


\title{
WORKS COUNCILS AND ENVIRONMENTAL INVESTMENT: THEORY AND EVIDENCE FROM GERMAN PANEL DATA
}

\begin{abstract}
Firms may underinvest in local environmental protection even from the private viewpoint of its owners and employees, but works councils may help mitigate this problem. We show that increases in environmental investments when councils are present could be employee-led, firm-led, or jointly-led. We test these alternatives with German panel data using a random effects probit model, and find a strong and robust relationship between investments in improving local environmental quality and council activities. This effect is largest and most significant when the council is active in environmental matters, and when management views employee participation as productive. With the exception of product innovation, we generally do not find analogous effects on investments that reduce environmental impacts more remote from the workplace, or for other types of investment. We conclude that the higher environmental investments in establishments with councils are largely employee-led or jointly-led; but the significant effect of management attitudes toward participation suggests that genuine management-employee cooperation and the tradeoffs it implies is taking place.
\end{abstract}

JEL Classification: J53, I18, J32, K32

\author{
Jan Erik Askildsen \\ Department of Economics \\ University of Bergen \\ Fosswinkelsgate 6 \\ 5007 Bergen \\ Norway \\ jan.askildsen@econ.uib.no
}

\author{
Uwe Jirjahn \\ Faculty of Economics \\ University of Hannover \\ Germany \\ jirjahn@mbox.iqw.uni-hannover.de
}

\author{
Stephan C. Smith \\ Department of Economics \\ George Washington University \\ USA \\ scsmith@gwu.edu
}

We would like to thank participants at the Tenth International IAFEP conference, University of Trento, Italy, and the Sixteenth Annual EEA congress, University of Lausanne, Switzerland, for helpful comments. This research has received financial support from The Research Council of Norway and Deutscher Akademischer Austauschdienst (DAAD). Askildsen is grateful to CESifo for hospitality during visit in April 2002. 


\section{Introduction}

This paper examines the impact of works councils on environmental investment by firms at the establishment level. These councils have been defined as "institutionalized bodies for representative communication between a single employer... and the employees... of a single plant or enterprise" (Rogers and Streeck, 1995, p. 6). This definition excludes conventional unions, quality circles and similar nonrepresentative participation, as well as most employee representation at the board level. Economic studies on works councils usually focus on the impact of works councils on firm productivity (FitzRoy and Kraft 1987), profits (Addison, Schnabel and Wagner 1996, Addison and Wagner 1997), dismissals, quits and hirings (Frick and Sadowski 1995) and the use of performance pay (Heywood, Hübler and Jirjahn 1998, Heywood and Jirjahn 2001). While councils might have additional effects on other aspects of firm performance and social welfare, the literature to date has not well recognized these aspects.

Vanek $(1970,1971)$ suggested that firms with substantial employee voice may invest more in pollution abatement than conventional firms, even though employees have to pay for it through reduced wages. ${ }^{1}$ Dreze (1976) and Dreze and Hagen (1978) derived related welfare benefits of employee voice in reducing occupational hazards in a general equilibrium setting. However, the role of councils in solving local environment underinvestment has not been examined, and little analytic treatment of employee voice in providing investment cooperation has been available. Our study is the first to address the involvement of works councils in environmental investments.

We investigate different kinds of environmental investments, which may have different effects for workers' and firm owners' utilities. Some environmental problems are workplace related, and thus correspond to what is usually termed workplace hazards. Several studies look at 
compensating wage differentials for job risks and adverse health effects related to the production activity (see e.g. Kim and Fishback (1999), and Siebert and Wei (1994)). Wage compensation is often determined through bargaining between unions and firms. Weil (1999) shows that mandated institutions may supplement the role played by unions in the enforcement of workplace regulations. Firms and workers may also be concerned with environmental impacts on locations away from the workplace, such as where workers or customers live, or that may have an effect on public relations or political scrutiny. To date, no empirical study has addressed the role of unions or cooperative arrangements such as works councils in solving external environmental impacts, for which employees and firm owners may have different interests depending on the type of environmental impact present and the distribution of its effects.

In this paper we consider three possible cases: First, workers prefer environmental investment to reduce occupational health problems or to reduce regional pollution affecting their families, but internalizing external effects is not profitable for owners. Second, management prefers environmental investment because it has positive productivity effects or public relations benefits. Third, both parties prefer environmental investment, though perhaps at different levels. We draw on the works council and codetermination literature, as well as recent bargaining literature, to show why there may be in all three cases underinvestment in pollution abatement activities even from the private point of view of the firm's owners and employees. Works councils may be an instrument for firms to implement investments or changes in organization in cases of imperfect contracts and concerns about opportunism. They may provide a credible institution because they can simultaneously influence investment activities and information flow, and thereby jointly allow for the interdependent effects of wage bargaining (alternatively effort bargaining) and bargaining on environmental or other investments. 
Similarly, McCain (1980) has argued that without codetermination or works councils, management and employees cannot bargain over all relevant working conditions or all dimensions of work effort. As a result, workplace characteristics over which bargaining is not feasible are determined unilaterally by one of the parties, and the resulting outcome may be Pareto inefficient. McCain developed a partial equilibrium model in which works councils make it feasible to bargain over these conditions, improving welfare.

To date, there has been almost no empirical evidence for the relationship between employee voice and environmental investment. Smith (1993) presents indirect evidence based on attitudinal responses of employees in U.S. firms with varying levels of employee participation, but argues that a revealed preference approach is needed. This paper provides revealed-preference based empirical evidence, using panel data from a random sample of manufacturing establishments in the state of Lower Saxony, Germany, to test hypotheses about the relationships between environmental investments, other forms of investment, and works councils. We examine the different implications of the employee-led and firm-led cooperative investment hypotheses, using data on environmental and other investments to help discriminate between them.

The empirical analysis is based on data from manufacturing establishments for the years 1993-1996. The analysis employs a random effects probit model. We find that the presence of a works council has a significantly positive effect on environmental investments. However, this effect is generally found only for investments that affect the workplace and the local community environment. There is no or little effect from councils on environmental 'friendliness' of firms' products, or on general innovations. Moreover, we find that councils that are 'active' in environmental matters have a substantially stronger effect than other councils. We also find that the positive effect of councils on environmental investments is substantially stronger when 
management considers employee participation to play a productive role in the firm. We conclude that the positive effect of councils on environmental investment is largely due to employee-led or jointly-led cooperative investments.

The remainder of the paper is organized as follows. The role of works councils in Germany is described in Section II. In Section III, we examine sources of underinvestment in local environmental quality, and develop the alternative scenarios of employee-led, firm-led, and jointly-led environmental investments. Section IV presents the data and results from the empirical analysis, and section $\mathrm{V}$ offers our conclusions.

\section{Works councils and their potential role in Environmental Investments in Germany}

In Europe, works councils have emerged from legal mandates. Germany, Norway, Denmark, Sweden, Austria, and the Netherlands require that workers have elected representation in Councils as well as at the board levels, while most of the remaining West European countries (excepting Britain) mandate Councils, though not board representation (see Rogers and Streeck, ed., 1995). In 1994, the European Union (EU) introduced regulations requiring European Works Councils for large and transnational firms.

In Germany, the Betriebsverfassungsgesetz, or Works Constitution Act (WCA), provides for the rights of employees to elect representatives to works councils (Betriebsräte) to jointly determine with management most aspects of workplace organization and activities. Note that employee involvement through works councils is entirely separate from the system of board-level co-determination, under legislation revised and expanded in 1976 (FitzRoy and Kraft 1993, 
2000). The WCA was introduced in 1952 and reformed in 1972 and 1989. All firm establishments with more than 5 employees are covered, though as a rule, the requirement that firms form councils has been enforced only when a complaint is filed that employees have requested the creation of councils. Hence, works councils are not present in all eligible establishments (Addison, Schnabel and Wagner 1997). The WCA provides for a high level of employee participation in all aspects of company planning, policies and operations. On some issues, councils have the right to information and consultation, in others a veto power over management initiatives, in still others the right to co-equal participation in the design and implementation of policy. For example, prior consultation with the council is necessary before the dismissal of any employee; employees have a right to continued employment until a judicial resolution or a settlement with the council is reached. For manpower planning and hiring new employees, the works council has only the right to be informed and make recommendations. Special activities such as employee questionnaires must have the approval of the works council. The works council must be informed of all important financial matters, including "the economic and financial situation of the company... the production and investment programs, rationalization plans, production techniques and work methods, especially the introduction of new work methods," plant closings, "changes in organization," and "any other circumstances and projects that may materially affect the interests of the employees of the company." With the revisions to the WCA in 1989 works councils gained enhanced consultation rights regarding the introduction of new technology.

While there is no explicit reference to environment, there are specific provisions for full rights of codetermination regarding occupational health and safety. Moreover, workers have the explicit right to be informed about any investment or other financial matters that might affect the 
employees. This formulation would clearly affirm the right to be informed in advance of any investments affecting the environmental impact of the firm, and would certainly appear to be supportive of the right to participate actively in decisions about their characteristics and scope. Additionally it can be argued that works councils can leverage their codetermination rights in other decision areas in order to bargain over environmental protection. Similarly, employees may trade off influence in a field covered by the WCA, but in which employees are less interested, for

influence in an area not explicitly covered, such as environmental investments. ${ }^{2}$ Therefore, it is clear that Councils participate actively in decisions concerning investments in new technologies (e.g., Wever, 1994).

In sum, works councils generally address a much broader set of decision areas beyond environmental matters, including working conditions and protection of firm specific human capital; and therefore a request for a works council by employees is generally separate from subsequent bargaining over environmental matters. However, if a works council is present, it is reasonable to assume, that the council can influence decisions about environmental investment. In our sample, we find that about 1 in 6 works councils are actively involved in environmental matters.

\section{Local Underinvestment in Environmental Quality and Works Councils}

It is well known that in the presence of transaction costs, the Coase theorem fails, and firms generally invest too little in environmental protection from the social viewpoint. It is less well appreciated that in the presence of transaction costs and other employment contract rigidities, 
firms may even invest too little in environmental protection, on a willingness-to-pay basis, from the internal viewpoint of its own managers and employees. In this section, we argue that there are likely to be market failures in environmental investment within a firm, which works councils may help to mitigate (one of the hypotheses tested in this paper). We consider both the workers' perspective and the employer's perspective.

\section{a. Employee-Led Environmental Investments}

There are two ways workers can be affected by environmental hazards caused by the firms in which they work. First, environmental hazards might contribute to ill health within the workplace during hours of work; specifically, it may affect occupational health. Second, workers and their families who live in the vicinity of the firms may suffer from regional pollution outside the workplace. These effects have tangible costs to employees, which in principle they may be willing to pay to abate. Costs of this type of hazard are likely to be felt less by owners, who may not live in the region, or if they do, are more able to afford housing that is not downwind or downstream of the plant. Note that in this framework employees would not be expected to have a greater interest in investments affecting geographically more diffuse impacts, such as product safety or reductions in greenhouse gas emissions. In such cases, only a small part of the impact is felt locally. Thus there is no claim implied that employees have stronger preferences for environmental investments than employers or managers per se. In fact, if top management is more concerned with general public relations at the corporation-wide level, they may have stronger preferences over product safety, greenhouse gas reductions, or other more diffuse impacts than nonmanagerial employees. Of course, ordinary workers also share a stake in the long-run financial wellbeing of the firm and its trademarks and reputation as a whole. However, 
they may be more interested in conditions in the plant (establishment) where they work, which may after all be sold to another firm; and in their local community, in which case a larger fraction of the benefits from environmental investments would directly impact their own welfare.

Letting $\mathrm{y}_{\mathrm{i}}$ denote worker i's income, $\mathrm{e}_{\mathrm{i}}$ denote worker i's effort, and $\mathrm{X}$ denote investments in reductions of environmental hazards, the utility function $\mathrm{U}_{\mathrm{i}}$ of worker $\mathrm{i}$ among $\mathrm{N}$ possibly heterogeneous employees is given by:

$$
\mathrm{U}_{\mathrm{i}}=\mathrm{U}_{\mathrm{i}}\left(\mathrm{y}_{\mathrm{i}}, \mathrm{e}_{\mathrm{i}}, \mathrm{X}\right), \mathrm{i}=1, \ldots, \mathrm{N},
$$

with $\partial \mathrm{U}_{\mathrm{i}} / \partial \mathrm{y}_{\mathrm{i}}>0, \partial \mathrm{U}_{\mathrm{i}} / \partial \mathrm{e}_{\mathrm{i}}<0$. The firm's profit is:

$$
\pi=\mathrm{Q}(\mathrm{X}, \mathrm{E})-\sum_{\mathrm{i}=1, \ldots, \mathrm{N}} \mathrm{y}_{\mathrm{i}}-\mathrm{C}(\mathrm{X})
$$

where $Q$ is output, $C(X)$ the cost of the environmental investments with $C^{\prime}(X)>0, C^{\prime \prime}(X) \geq 0$, and $\mathrm{E}$ is the sum of efforts:

$$
\mathrm{E}=\sum_{\mathrm{i}=1}^{\mathrm{N}} \mathrm{e}_{\mathrm{i}} .
$$

In this section we consider the case of employee-led investment. This case is characterized by $\partial \mathrm{U}_{\mathrm{i}} / \partial \mathrm{X}>0$ and $\partial \pi / \partial \mathrm{X}<0$. The employer's preferences for environmental investment depend on $\mathrm{Q}()-.\mathrm{C}(\mathrm{X})$. It may be argued that environmental investments internalize external costs, so that they would (on the margin) reduce profits as well as conventionally measured productivity, even as social welfare would generally (on the margin) increase. Therefore, environmental investments would impose net costs on the employer. In this case workers who gain utility from environmental protection have to pay for it through lower wages or higher effort. In equation (1) we consider environmental protection as a workplace public good. Assuming that an aggregation method is available, equating the sum of marginal rates of substitution with the marginal rate of 
transformation between wages and pollution abatement implied by constraining the firm's profit not to fall below a given level, yields the locally efficient solution:

$$
\sum_{i=1}^{N} \frac{\partial U_{i} / \partial X}{\partial U_{i} / \partial y_{i}}=\frac{\partial \pi / \partial X}{\partial \pi / \partial y_{j}}
$$

with $\partial \pi / \partial y_{j}=-1(j=1, \ldots, N)$. Similarly, we may find the tradeoff between effort and environment, as

$$
\sum_{\mathrm{i}=1}^{\mathrm{N}} \frac{\partial \mathrm{U}_{\mathrm{i}} / \partial \mathrm{X}}{\partial \mathrm{U}_{\mathrm{i}} / \partial \mathrm{e}_{\mathrm{i}}}=\frac{\partial \pi / \partial \mathrm{X}}{\partial \pi / \partial \mathrm{e}_{\mathrm{j}}}
$$

with $\partial \pi / \partial \mathrm{e}_{\mathrm{j}}=\partial \mathrm{Q}(.) / \partial \mathrm{E}(\mathrm{j}=1, \ldots, \mathrm{N})$.

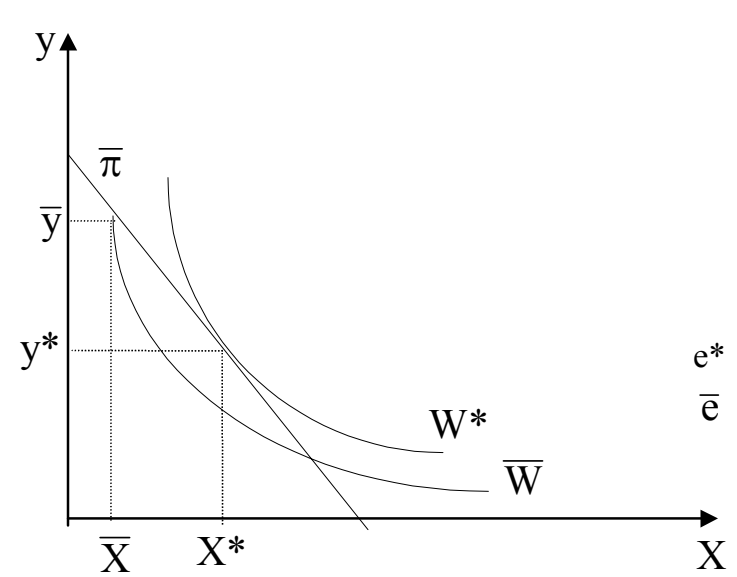

Figure 1a

Employee-Led Investment Income-Public Good Tradeoff

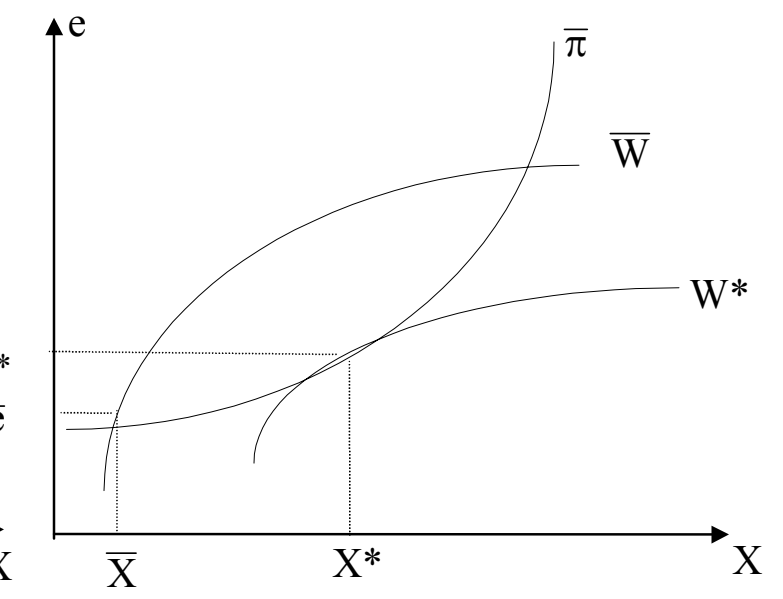

Figure $1 b$

Employee-Led Investment Effort-Public Good Tradeoff

In Figures $1 \mathrm{a}$ and $1 \mathrm{~b}$ we show these tradeoffs. $\overline{\mathrm{X}}$ is the minimum level of environmental investment/protection required to comply with the (environmental, labor, or other) law. In figure 1a, $\bar{y}$ is the collectively bargained wage or the reservation wage that workers receive elsewhere; 
$\bar{\pi}$ is the corresponding profit level, and $\overline{\mathrm{W}}$ is the workers' welfare. Workers would maximize their welfare function at the point $\left(\mathrm{y}^{*}, \mathrm{X}^{*}\right)$. Employers and workers could be better off by bargaining an income $\mathrm{y}^{*}<\mathrm{y}<\overline{\mathrm{y}}$ and an environmental investment $\overline{\mathrm{X}}<\mathrm{X}<\mathrm{X}^{*}$ at or below $\bar{\pi}$ and at or above $\overline{\mathrm{W}}$. Alternatively, they can bargain over effort. In Figure $1 \mathrm{~b}, \overline{\mathrm{e}}$ is a baseline effort level that is assumed to be verifiable. Employees and owners could be better off when they bargain an effort level $\overline{\mathrm{e}}<\mathrm{e}<\mathrm{e}^{*}$ and environmental investment $\overline{\mathrm{X}}<\mathrm{X}<\mathrm{X} *$ at or below $\overline{\mathrm{W}}$ and at or above $\bar{\pi}$.

Although workers are willing to trade off wages or effort for reduced pollution by the firm, even a locally efficient solution like that given by equation (3) and (4) may not be implemented without a works council. First, as Dreze and Hagen (1978) have shown, it may be impossible for workers to express these preferences through the market through hedonic wages in general equilibrium. Thus, in general, competitive profit maximization does not imply an efficient choice of working conditions. $^{3}$

When the price mechanism fails to express worker preferences why don't workers directly communicate their preferences to the management? One problem is that, as seen in (3) and (4) above, environmental protection is a workplace public good. ${ }^{4}$ As Freeman and Medoff (1984) argue, the individual-voice mechanism is not effective in the case of workplace public goods. First, there is a positive external effect of individual voice because other workers gain from individually negotiated improvements in working conditions. Put differently, there is a free rider problem, as with any other public good. Second, any bargaining costs are imposed on the individual worker. Each worker would have to collect data to support his or her views, and incur costs of verifying any claims made by management. Therefore a collective voice institution may 
in general be necessary to communicate worker preferences to the managers. In Germany works councils exert this collective voice role (FitzRoy and Kraft 1987; Frick and Sadowski 1995).

Moreover, transaction costs and coordination problems might prevent management from bargaining efficiently with each worker. On the one hand, without coordination, it will be difficult for an individual worker to know the extent to which his or her preferences are shared by other employees. Even if it is known that preferences are shared, to implement a technology preferred by workers, it might be necessary for each worker to invest in strongly complementary skills. These could be specific skills having little value if the firm doesn't make the investment in the new technology, or if other workers do not make parallel human capital investments.

In addition, potential commitment problems are present. This is especially likely when the firm bargains with each worker and transaction costs prevent the parties from writing an explicit contract for each worker. In this case workers might fear the employer's ex-post opportunism (Dow 1987; Smith 1991; Askildsen and Ireland 1993; Freeman and Lazear 1995). Even if there are no free rider problems, workers may not be willing to reveal their preferences when they fear other uses of the revealed information by the employer. For example, workers might fear the loss of jobs due to technological change. Or, they may fear that management might not make agreed environmental or other investments ex post, by claiming that the workers didn't exert enough effort or maintain some other part of the agreement that may be difficult to verify. Providing works councils with codetermination rights is one mechanism for building cooperative and trustful industrial relations. Of course, under some circumstances repeated games and reputation concerns can solve the commitment problem (Bull 1987; Baker, Gibbons and Murphy 1994). However, the reputation mechanism may not work, because of high discount rates. ${ }^{5}$ Councils provided with veto rights can protect the workers' interests even if an employer does not care 
about her reputation. Moreover, the reputation mechanism will not work, if employees do not have enough information to verify whether or not an employer behaved honestly (Kreps 1990). This suggests that the comprehensive information rights of the works councils and the reputation mechanism may be complementary.

The above arguments imply that there exist not-very-restrictive circumstances under which the market may be unable to induce workers to reveal and aggregate their preferences for environmental protection and to contract an explicit or implicit agreement reflecting those preferences with the employer. Without a works council workers and employer may get stuck in a situation characterized by an environmental underinvestment. This situation is depicted in figure 1a by the point $(\overline{\mathrm{y}}, \overline{\mathrm{X}})$, respectively $(\overline{\mathrm{e}}, \overline{\mathrm{X}})$ in figure $1 \mathrm{~b}$. Works councils may help to overcome the market failures in environmental quality by providing a channel for communication between workers and management and by creating trust and loyalty. Therefore, works councils may facilitate bargaining over environmental quality. This results in an environmental investment $\overline{\mathrm{X}}<\mathrm{X}<\mathrm{X}^{*}$.

\section{b. Firm-Led and Jointly-Led Environmental Investments.}

In an alternative scenario we may assume that, up to some point, environmental investments may have a positive productivity effect on profitability, through increased productivity as in equation (2), or some other channel including public relations benefits that may lead to an increase in revenues or a decrease in costs. ${ }^{6}$ In such cases, management may prefer a positive level of environmental investment, even if the regulatory constraint does not bind. Thus, in this case we assume that $\partial \pi / \partial \mathrm{X}>0\left(\partial \mathrm{Q}(.) / \partial \mathrm{X}>\mathrm{C}^{\prime}(\mathrm{X})\right)$ up to some level and that $\partial \pi / \partial \mathrm{X}<0$ $\left(\partial \mathrm{Q}(.) / \partial \mathrm{X}<\mathrm{C}^{\prime}(\mathrm{X})\right)$ beyond this level, as reflected in Figures 2 and 3. For a given worker 
income and effort level the profit maximizing environmental investment $\mathrm{X}^{*}$ (for an interior solution) is given by the first-order condition $\partial \mathrm{Q}(.) / \partial \mathrm{X}-\mathrm{C}^{\prime}(\mathrm{X})=0$. This situation is depicted for income and environmental investment. ${ }^{7}$

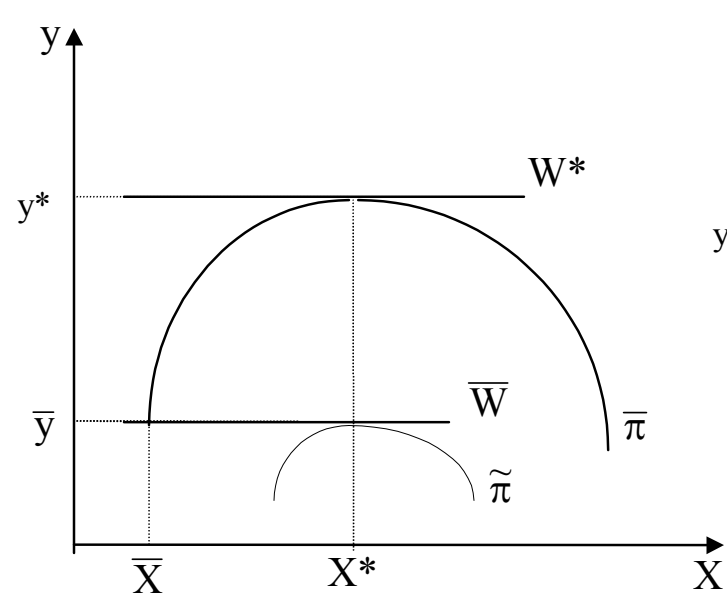

Figure 2

Firm-Led Investment

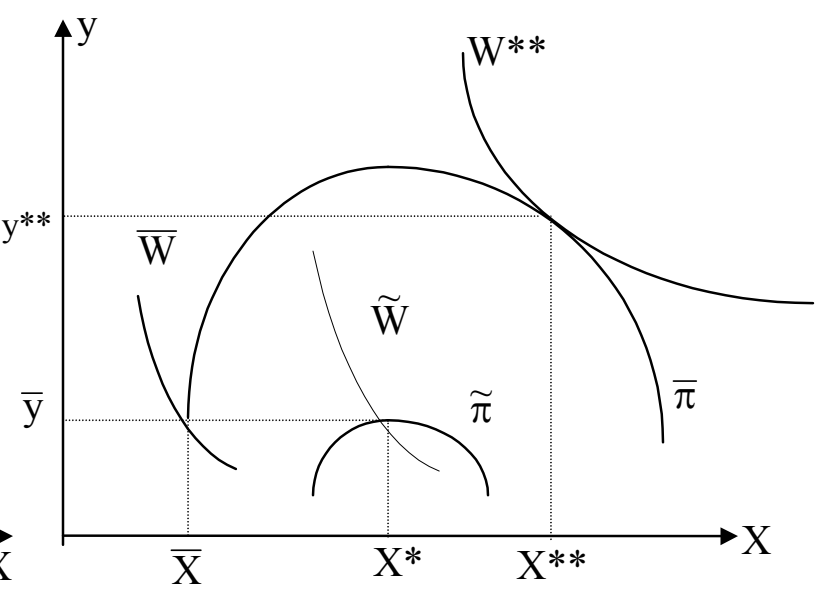

Figure 3

Jointly Led Investment

In Figures 2 and 3 above, $\bar{X}$ is the minimum level of environmental investment required to comply with the law; $\bar{y}$ is the reservation wage (or the collectively bargained wage if applicable); $\bar{\pi}$ is the corresponding profit level; and $\overline{\mathrm{U}}$ denotes the workers' welfare. Note that the firm's iso-profit curve, $\bar{\pi}$, has its maximum at $X^{*}$. Up to $X^{*}$ employers would be willing to pay for a higher environmental protection through higher wages, if necessary, to ensure that workers cooperate with technological change.

Figure 2 depicts the firm-led investment case, in which workers value only income, treating environmental protection as a neuter good at least in the relevant range. In principle, if the investment caused some disutility due to unpleasant working conditions, the investment could also be viewed as a bad. Given the restriction that the firm receives its reservation profit 
workers would maximize their welfare at the point $\left(\mathrm{y}^{*}, \mathrm{X}^{*}\right)$. Conversly, given the restriction that workers receive their reservation utility the firm would maximize its profit at the point $\left(\bar{y}, X^{*}\right)$. The respective profit is depicted by the iso-profit curve $\tilde{\pi}$. As before the parties could be better off when there is a possibility to bargain over income and environmental protection: $\bar{y}<y<y^{*}$ and $\overline{\mathrm{X}}<\mathrm{X}<\mathrm{X}^{*}$. Note that employee incomes resulting from the bargaining process over environment and incomes are higher when we consider positive productivity effects of environmental investment.

The incomplete contracting arguments above can also be applied to the case of employer-led investment. If information about potential firm performance-enhancing environmental innovations are in the hands of the employer, employees might have an interest in sabotaging these investments when they fear that such innovations might have other effects such as adversely affecting bargaining power. However, if the information is in the hands of employees, they may not wish to reveal it due to fear of management opportunism. For example, the information might reduce employee bargaining power, or facilitate changes that reduce employment or have other consequences that employees view as against their interests (Dow 1993; Freeman and Lazear 1995). Therefore, bargaining over environmental investment is more likely when a works council is present, if it is perceived by the employees as protecting their interests.

Figure 3 depicts jointly-led investment. To a significant degree the parties share a common interest in investment, up to the level $\mathrm{X}^{*}$. Holding effort and income constant the workers' welfare and the firm's profit would increase to $\widetilde{\mathrm{W}}$ and $\tilde{\pi}$ when the firm invests in environmental protection up to $\mathrm{X}^{*}$. At $\left(\overline{\mathrm{y}}, \mathrm{X}^{*}\right)$ social welfare, profits and productivity are increased. It might 
seem that in this situation works councils are not necessary for the aggregation of preferences and for bargaining over environmental investment. However, the above arguments indicate that also in this situation commitment problems are possible; when workers fear management opportunism (e.g. the loss of jobs due to process innovation), they may find it in their interests to refuse cooperation. Moreover, workers prefer to extend environmental investment beyond $\mathrm{X}^{*}$. Workers would maximize utility subject to the given profit level, $\bar{\pi}$, at the point $\left(\mathrm{y}^{* *}, \mathrm{X}^{* *}\right)$. Although environmental investments might still have positive productivity effects $\left(0<\partial \mathrm{Q}(.) / \partial \mathrm{X}<\mathrm{C}^{\prime}(\mathrm{X})\right)$, the strong preferences for environmental investment result in partially conflicting interests between workers and the employer regarding environmental investment, and so the aggregation of preferences and bargaining are of greater importance. In sum, employers and workers could be better off by bargaining an income $y^{* *}<y<\bar{y}$ and an environmental investment $\overline{\mathrm{X}}<\mathrm{X}<\mathrm{X}^{* *}$ at or below $\bar{\pi}$ and at or below $\overline{\mathrm{W}}$.

\section{Empirics}

We may derive three hypotheses from the theoretical considerations. The first is the employee-led environmental investment hypothesis: Workers prefer environmental investments, but internalizing external effects is not profitable for owners; or management may behave opportunistically once workers become committed to tradeoffs to gain these investments. The works council provides a "voice institution" enabling the aggregation of preferences and subsequent bargaining over tradeoffs for environmental investment. The second hypothesis is that of firm-led environmental investment: Management prefers environmental investment; and 
the works council then provides a mechanism to successfully implement these investments. The third possibility is the jointly-led investment hypothesis; both parties prefer environmental investments, though perhaps at different levels, but they need a mechanism for cooperation to successfully implement them. In each case the works council enables the introduction of augmented environmental protection, although the underlying reasons for this differ.

\section{a. Data Set and Variables}

The empirical analysis is based on four waves (1994-1997) of a panel study (Hannover Panel) of manufacturing establishments in the German federal state Lower Saxony (Brand et al. 1996). The population consists of all manufacturing establishments with at least 5 employees. The sample is stratified according to firm size and industry. The data were collected on the basis of a questionnaire in personal interviews with the owner, top manager or head of the personnel department. The number of firms taking part in the panel study declined from 1,025 (1994) to 849 (1995), 721 (1996) and 709 (1997).

The data set includes detailed data on profit sharing, work organization and employee motivation. In particular it includes data on works councils and on environmental investments; and it provides numerous control variables. Further, firms are asked whether the Council is active in making decisions about "environmental protection questions." This is one of our key variables for considering the impact of the Council. In addition to questions directly concerning the Council, there are questions that should cast light on the strength of its role within the establishment, as what might be termed "Council complements". The survey asks management attitudes on motivating employees by strengthening employee involvement in decision making. 
When this answer is coupled with the presence of a Council, this may be taken as a potential indicator of the strength of its role.

As independent variables we consider, alternatively, WOCO, indicating the presence of a works council, and ACWOCO, indicating the presence of a works council that is 'active' in the field of environmental investments. We also consider the variables WINVOLV and WNOVOLV, which indicate, respectively, whether management considers employee participation as 'good' or 'bad' for decision making in the presence of a council. Finally, we use the variables ACINVOLV and ACNOVOLV, which indicate, respectively, whether management considers employee participation as 'good' or 'bad' for decision making in the presence of an 'active' council.

The data set is also unique in that it offers a range of information about types of environmental investments. Table 1 in Appendix presents the descriptive statistics of all variables used. Our dependent variables include responses to questions concerning existence of investments which would reduce pollution or improve the environment. ENVDUM is a dummy variable that takes the value of 1 if the establishment invests in measures to "reduce its contribution to environmental pollution" and 0 otherwise. ENV1-4 are dummy variables that take the value of 1 if the establishment invests (for the purpose of reducing environmental pollution) respectively with 1) improvement of an existing production process or introduction of a new one, 2) down-the-line technology, 3) waste management/recycling, and 4) employees' education 'to increase their environmental consciousness.' Finally, ENVPROD is a dummy variable equal to 1 if the establishment introduces new 'environmentally-friendly' products. Some dependent variables such as ENVDUM and ENV1-4 are workplace related, or relevant for the vicinity of the production unit, whereas others such as ENVPROD are more related to the products provided by the establishment. To sharpen the interpretation of our results, we also 
investigate the effects of works councils on general innovative activities in products or production processes, given respectively by INNOV1 and INNOV2. Informations on environmental investments and innovations are available in each wave and refer to the years $1993-1996 .^{8}$

\section{b. Results}

The results are reported in Tables 2 through 5, which due to length are reported in Appendix. With the dependent variables as a categorical ('no', 'yes'), and firm-specific characteristics likely to play a significant role in investment decisions, we have used a random-effects-probit model (Butler and Moffit 1982) in the estimations, controlling for an establishment-specific and timeinvariant error component. It should be noted that 12 industry dummies are included to control for industry specific pollution levels, due to differing degrees of pollution and varying abatement technology across industries. In order to economise on space, in Tables 2-5 (see Appendix) the coefficients of these dummies are suppressed.

In Table 2, we report regression results using WOCO, indicating the existence of a works council, as the works council explanatory variable for each of the dependent variables. As seen in Table 2, WOCO has a positive coefficient that is statistically significant and quantitatively large in each of the first five regressions, in which the investment in question likely affects the workers directly. On the other hand, the coefficient on WOCO is insignificant in the regression on ENVPROD, which represents investments that are less likely to affect workers directly, or that have an impact that is more remote from the work place. It is also insignificant in the regression on INNOV2, which reflects investments in general process innovation, with no obvious direct effect on workers. Taken together, these findings provide support for the employee-led 
investments hypothesis, that workers will use the channels of participation to reduce pollution from the firm that may affect their own jobs and neighborhoods. However, there is one exception to this pattern: in the regression on INNOV1, indicating the introduction of new products, the coefficient is positive and significant, though only at the $10 \%$ level. This finding suggests that some non-environmental investments may also be facilitated in the presence of works councils, and may likely be firm-led.

Several of the other determinants of these investments are of interest in their own right. The use of team-based production processes is a positive determinant for each of the eight investment variables, and is statistically significant for all but INNOV1. The presence of profit sharing is a positive, statistically significant determinant for all but ENV3 and ENVPROD, where the coefficients are insignificant. Both of these independent variables may be viewed as reflecting alternative forms of 'participation,' so it is of interest that each tends to have an independent significant effect. However, the presence of collective bargaining is significant only in the regression on ENVPROD, where its coefficient is negative.

We also find a positive and significant coefficient for MGTPRSH, a variable indicating that there is a profit sharing plan for the establishment's managers, in the regressions on ENVDUM, ENV1 and ENV4. This result may suggest that management favors these types of investments, thus possibly providing some evidence in favor of the firm-led (or jointly-led) investment hypothesis. One role of profit sharing is to align incentives of employees more closely with those of owners (i.e., it is an 'agency' variable), and thus the positive effect of both employee and management profit sharing on at least some investment variables may suggest that these investments are favored by management. However, we do not know what workers may give up explicitly or implicitly in exchange for such investments. 
As might be expected, firms that are larger, emphasize the role of research in company strategy, use the most recent vintage production machinery, and do more training, are more likely to make both general and environmentally-oriented investments.

Interestingly, the probability of environmental investments affecting local workers tends to be increasing in the share of blue collar workers, but the probability of investments in 'environmentally-friendly' products and in new products in general is decreasing in the blue collar share. Blue collar workers may be especially concerned with the local pollution impact of the firm because they are more likely to be affected by environmental hazards.

Results for REMARKET (a variable indicating that the regional market is the most important market for the firm) are also of interest. We find a positive and significant coefficient on REMARKET for two of the local environment variables, ENV2 and ENV3; this may reflect the importance of regional reputation on pollution abatement to these firms. On the other hand, we find a negative and significant coefficient for INNOV1, which may suggest that a sufficiently large market is necessary to provide an adequate rate of return on new product innovation.

Because these other determinants are robust to the specification of the works council variable, in later tables we report only the coefficients on the council variables. In Table 3, we present regression results in which, in place of WOCO, we substitute as an independent variable ACWOCO, which indicates the existence of a works council that is active in environmental topics. This specification results in a sharpening of the distinction between environmental investments, likely to affect local residents, and general investments. It is voluntary for works councils to participate in environmental investment matters, so the variable ACWOCO provides an indication of the strength of employee environmental preferences. As it turns out, the coefficient on ACWOCO in the regressions on the five local environment variables, ENVDUM 
and ENV1-4 are all positive and statistically significant, while those on regressions for the three other variables, ENVPROD and INNOV1-2, are all insignificant. Moreover, in this alternative specification the significant coefficients are generally much larger in magnitude.

In Table 4 we report regression results obtained by substituting two alternative independent variables for works council involvement. The first row reports the coefficients on the interaction of works council presence with management responses indicating positive views toward workers' involvement in decision making (this interaction variable is designated as WINVOLV). The second row reports the interaction with management responses indicating negative views (WNOVOLV). Results for WINVOLV are broadly similar to those reported in Tables 2 and 3. The notable difference is that the coefficient on INNOV1 is now statistically significant at the $5 \%$ level (this coefficient was significant at the $10 \%$ level in the regression using WOCO as an independent variable). Strikingly, when we use the WNOVOLV variable, none of the coefficients are statistically significant. Apparently, management attitude toward the works council makes a great deal of difference for its ultimate impact. It should be noted that positive views toward participation are prevalent in the sample of firms reporting a works council. While the incidence of WINVOLV is $49.4 \%$, the incidence of WNOVOLV is just $8.5 \%$.

In Table 5, we consider a final specification of the works council variable. In the first row we consider the impacts of the interaction between environmentally active councils and positive management attitudes toward employee participation (this interaction variable is designated as ACINVOLV). Results are broadly similar to those in the first row of Table 4, although the coefficient on INNOV1 is no longer significant. In addition, as might be expected, both from theory and from the earlier results from Tables 2 and 3, the coefficients of ACINVOLV (Table 5) are generally larger than those of WINVOLV (Table 4). 
In the second row of Table 5 we consider the impacts of the interaction between environmentally active councils and negative management attitudes toward employee participation (this interaction variable is labeled ACNOVOLV). The only difference in statistical significance, in comparison with the results on WNOVOLV in the second row of Table 4, is that the coefficient of ACNOVOLV is negative and significant in the regression on ENV3.

The latter results give some support for the jointly-led investments interpretation of the role of works councils. Councils have their largest effect when they are both active on a topic (in this case on environmental investments) and at the same time management believes that employee decision making participation is productive.

\section{Concluding Remarks.}

This paper examined the impact of works councils on environmental investment by firms at the establishment level. We argued that firms may underinvest in local environmental protection even from the private viewpoint of the firm's owners and employees, but that works councils may play a role in redressing this problem. We showed that increases in investment in environmental protection in the presence of works councils could be either employee-led, firmled, or jointly-led. These alternatives were then tested using panel data from a random sample of manufacturing establishments in Lower Saxony, Germany.

We found that among establishments with works councils, about 1 in 6 have councils that are directly involved in environmental matters. Using a random effects probit model, we found a strong and robust relationship between firms' investments in improving local environmental 
protection and works council activities. This effect was largest and most significant when the works council is active in environmental matters, and when management views employee participation to be productive for the firm. While there are some exceptions, notably in product innovation, for the most part we did not find analogous effects on investments that would reduce environmental impact of the firm in ways more remote from the workplace and the neighborhood of the firm, or for other types of investment. We concluded that much but not all of the increased investment in environmental protection in establishments with councils is employee-led, or possibly jointly-led, rather than firm-led.

However, the role of management attitudes suggests that genuine cooperation and the tradeoffs it implies appears to be a key part of the explanation for the positive effect of works councils on environmental investment. The positive coefficient of works councils in the regression on new product innovation offered some evidence that councils also facilitate the implementation of some firm-led investments. Some additional support for this view is found in the observation that works councils have their largest effect when they are active on environmental investment matters and management believes that employee decision-making participation is productive. 


\section{References}

Addison, John T., Claus Schnabel, and Joachim Wagner (1996), "German Works Councils, Profits, and Innovation," Kyklos, 49(4), 555-82.

Addison, John T., Claus Schnabel, and Joachim Wagner (1997), “On the Determinants of Mandatory Works Councils in Germany," Industrial Relations, 36(4), 419-45.

Addison, John T. and Joachim Wagner (1997), “The Impact of German Works Councils on Profitability and Innovation: New Evidence from Micro Data,” Jahrbücher für Nationalökonomie und Statistik, 216(1), 1-20.

Askildsen, Jan Erik, and Norman J. Ireland (1993), "Human Capital, Property Rights and Labour Managed Firms," Oxford Econmic Papers 45, 229-242.

Baker, G., R. Gibbons, and K.J. Murphy (1994), "Subjective Performance Measures in Optimal Incentive Contracts," Quarterly Journal of Economics 109,1125-1156.

Bertrand, M. (1999), "From the Invisible Handshake to the Invisible Hand? How Import Competition Changes the Employment Relationship,” NBER Working Paper No. 6900.

Brand, Ruth, Vivian Cartensen, Knut Gerlach, and Thomas Klodt (1996), “The Hannover Panel,” Discussion Paper No. 2, Forschungsstelle Firmenpanel, Univ. of Hannover.

Bull, Clive (1987), “The Existence of Self-Enforcing Implicit Contracts,” Quarterly Journal of Economics, 102, 147-159.

Butler, J.S. and R. Moffit (1982), "A Computationally Efficient Quadrature Procedure for the One Factor Multinomial Probit Model," Econometrica 50, 761-764.

Dow, Gregory (1993), "Why Capital Hires Labor: A Bargaining Perspective," American Economic Review, 83, 118134.

Dow, Gregory, (1987), "The Function of Authority in Transaction Cost Economics," Journal of Economic Behavior and Organization, $8(1), 13-38$.

Dreze, Jacques (1976), “Some Theory of Labor Management and Participation,” Econometrica, 44, 1125-1140

Dreze, Jacques, and Kare P. Hagen (1978), “Choice of Product Quality: Equilibrium and Efficiency,” Econometrica, 46, 493-513.

FitzRoy, Felix R., and Kornelius Kraft (2000), “Co-Determination, Efficiency, and Productivity,” Working Paper, University of Essen, Germany.

FitzRoy, Felix R., and Kornelius Kraft (1993), “Economic Effects of Codetermination, ” $\underline{\text { Scandinavian Journal of }}$ Economics, 95, 365-75.

FitzRoy, Felix R., and Kornelius Kraft (1987), “Efficiency and Internal Organization: Works Councils in West German Firms," Economica, 54, 493-504.

Freeman, Richard B., and Edward P. Lazear (1995), “An Economic Analysis of Works Councils,” in Rogers and Streeck (eds.), 27-52.

Freeman, Richard B. and James L. Medoff (1984), What Do Unions Do? New York: Basic Books. 
Frick, Bernd, and Dieter Sadowski (1995), “Works Councils, Unions, and Firm Performance: The Impact of Workers' Participation in Germany," in: Friedrich Buttler et al. (eds.), Institutional frameworks and labor market performance: Comparative views on the U.S. and German economies, New York: Routledge, 46-81.

Heywood, John S., Olaf Hübler and Uwe Jirjahn (1998), "Variable Payment Schemes and Industrial Relations: Evidence from Germany," Kyklos, 51, 237-257.

Heywood, John S., and Uwe Jirjahn (2001), "Payment Schemes, Gender and Industrial Relations in Germany," Industrial and Labor Relations Review, forthcoming.

Kreps, David M. (1990), "Corporate Culture and Economic Theory," in: J.E. Alt and K.A. Shepsle (eds.), Perspectives on Positive Political Economy, Cambridge: Cambridge University Press, 90-143.

Kim, Seung Wook, and Price V. Fishback (1999), “The Impact of Institutional Change on Compensating Wage Differentials for Accident Risk: South Korea, 1984-1990”, Journal of Risk and Uncertainty, 18, 231-248.

McCain, Roger A. (1980), “A Theory of Codetermination,” Zeitschrift fur Nationalökonomie, 40, 65-90.

Müller-Jentsch, Walther (1995), “Germany: From Collective Voice to Co-management,” in Rogers and Streeck (eds.), 53-78.

Porter, Michael E., and Claas van der Linde, (1995), "Toward a New Conception of the Environment Competitiveness Relationship," Journal of Economic Perspectives, 9, 97-118.

Rogers, Joel, and Wolfgang Streeck (1995, eds.), Works Councils. Consultation, Representation, and Cooperation in Industrial Relations, Chicago: University of Chicago Press.

Siebert, W. Stanley, and X. Wei (1994), “Compensating Wage Differentials for Workplace Accidents: Evidence for Union and Nonunion Workers in the UK", Journal of Risk and Uncertainty, 9, 61-76.

Smith, Stephen C. (1991), "On the Economic Rationale for Codetermination Law," Journal of Economic Behavior and Organization, 12, 261-81.

Smith, Stephen C. (1993), "Worker Participation and Workplace Public Goods: Some Theory and Attitudinal Evidence from U.S. Labor-Managed and Codetermined Firms," in S. Mahalingham et. al. (eds.), Labour Participatory Economy, Mittal, 69-93.

Vanek, Jaroslav (1970), The General Theory of Labor-Managed Market Economies, Ithaca, NY: Cornell University Press.

Vanek, Jaroslav (1971), The Participatory Economy, Ithaca, NY: Cornell University Press.

Weil, David (1999), "Are Mandated Health and Safety Committees Substitutes for or Supplements to Labor Unions?" Industrial and Labor Relations Review, 52, 3, 339-360.

Wever, Kirsten S. (1994), “Learning from Works Councils: Five Unspectacular Cases from Germany,” Industrial Relations," 33, 467-81. 


\section{Appendix: Tables 1-5.}

Table 1: Variable Definitions and Descriptive Statistics

ENVDUM

ENV1

ENV2

ENV3

ENV4

ENVPROD

INNOV1

INNOV2

ABSENT

ACWOCO

ACINVOLV

ACNOVOLV

AG

AGE70

AGE80
Dummy variable equal to 1 if the establishment invests in measures to reduce its contribution to environmental pollution $(0.545,0.498,2911)$

Dummy variable equal to 1 if the establisment invests in the improvement of a existing production process or in the introduction of a new production process (e.g. circulation flow management) to reduce environmental pollution $(0.234,0.424,1978)$

Dummy variable equal to 1 if the establishment invests in down-the-line technology (e.g. filter and purification technology) to reduce environmental pollution $(0.300$, $0.459,1978)$

Dummy variable equal to 1 if the establishment invests in waste management/recycling $(0.336,0.473,1978)$

Dummy variable equal to 1 if the establishment invests in the employees' education to increase their environmental consciousness $(0.198,0.398,1978)$

Dummy variable equal to 1 if the establishment introduces new environmentalfriendly products $(0.108,0.311,2914)$

Dummy variable equal to 1 if the establishment introduces new products $(0.510$, $0.500,2916)$

Dummy variable equal to 1 if the establishment introduces new production processes $(0.211,0.408,2917)$

Dummy variable equal to one if management feels that excessive absenteeism is a personnel problem in the establishment $(0.278,0.448,2911)$

Dummy variable equal to 1 if a works council is present in the establishment and the works council takes care of environmental protection questions $(0.098,0.297,2813)$

Dummy variable equal to 1 if a works council takes care of environmental protection questions in the establishment and management feels that strengthening worker involvement in decision making is an appropriate measure to increase employee motivation $(0.087,0.282,2813)$

Dummy variable equal to 1 if a works council takes care of environmental protection questions in the establishment and management feels that strengthening worker involvement in decision making is no appropriate measure to increase employee motivation $(0.011,0.104,2813)$

Dummy variable equal to 1 if the establishment is a Public Limited Company (0.036, $0.186,2911)$

Dummy variable equal to 1 if the establishment was created between 1970 and 1979 in Lower Saxony $(0.093,0.290,2911)$

Dummy variable equal to 1 if the establishment was created between 1980 and 1989 
in Lower Saxony $(0.097,0.295,2911)$

AGE90

Dummy variable equal to 1 if the establishment was created at the beginning of the nineties in Lower Saxony $(0.031,0.174,2911)$

MGTPRSH

Dummy variable equal to 1 if executive managers have a profit sharing plan $(0.443$, $0.497,2911)$

BLUECOL Blue collar workers as a proportion of total employees $(0.627,0.187,2911)$

COLLECT

Dummy variable equal to 1 if the establishment is covered by a collective bargaining agreement $(0.651,0.477,2911)$

CONC

Sales of the six largest companies in each industrial sector as a share of total sales in the sector. Official German statistics from 1993 are matched to 32 industrial sectors identified by the survey $(17.473,14.694,2911)$

CONCSQD CONC squared

GMBHKG

Dummy variable equal to 1 if the establishment is a Limited Partnership with Limited Company as a Limited Partner $(0.299,0.458,2911)$

INDUSTRY DUMMIES Dummy variables for 12 from 19 broad divided industrial groups in the manufacturing sector

PR

Dummy variable equal to 1 if strengthening public relations, advertising and/or marketing is the heart of the establishment's strategy $(0.216,0.412,2911)$

PRSHARE

REMARKET

Dummy variable equal to 1 if the establishment provides profit sharing to employees other than executives $(0.163,0.369,2911)$

Dummy variable equal to 1 if the regional market is the most important market for the establishment's most important product group $(0.310,0.463,2911)$

RESEARCH

Dummy variable equal to 1 if strengthening research and development is the heart of the establishment's strategy $(0.211,0.408,2911)$

SIZE

Total employees in the establishment divided by $1000(0.174,0.683,2911)$

SIZESQD

SIZE squared

STRUC

Dummy equal to 1 if the establishment has no subsidiaries and is not itself a subsidiary $(0.596,0.491,2911)$

TEAM

Dummy variable equal to 1 if blue-collar workers are organized in production teams with expanded involvement in decision-making and increased responsibility $(0.496$, $0.500,2911)$

TECH

Dummy variable equal to 1 if the production machinery is of the most recent vintage $(0.342,0.474,2911)$

TRAIN

Dummy variable equal to 1 if the establishment finances continuous training for the employees $(0.586,0.493,2911)$

WOCO

Dummy variable equal to 1 if a works council is present in the establishment $(0.585$, 
WINVOLV

WNOVOLV

WOMEN
Dummy variable equal to 1 if a works council is present in the establishment and and management feels that strengthening worker involvement in decision making is an appropriate measure to increase employee motivation $(0.494,0.500,2868)$

Dummy variable equal to 1 if a works council is present in the establishment and and management feels that strengthening worker involvement in decision making is no appropriate measure to increase employee motivation $(0.085,0.279,2868)$

Women as a proportion of total employees $(0.286,0.235,2911)$

Notes: The descriptive statistics are for the samples pooled in table 2. The descriptive statistics for ACWOCO, WINVOLV, WNOVOLV, ACINVOLV, ACNOVOLV are for the samples pooled in table 3, 4 and 5. Mean, standard deviation and number of observations are in parentheses. 
Table 2 Random Effects Probit. Works council (WOCO).

\begin{tabular}{|c|c|c|c|c|c|c|c|c|}
\hline \multirow[b]{2}{*}{ Exogenous Variables } & \multicolumn{2}{|c|}{ ENVDUM } & \multicolumn{2}{|c|}{ ENV1 } & \multicolumn{2}{|l|}{ ENV2 } & \multicolumn{2}{|c|}{ ENV3 } \\
\hline & $\hat{\beta}$ & $|t|$ & $\hat{\beta}$ & $|t|$ & $\hat{\beta}$ & $|t|$ & $\hat{\beta}$ & $|t|$ \\
\hline Constant & $-0.5578 * *$ & 2.046 & $-1.7970 * *$ & 5.565 & $-1.9316^{* *}$ & 6.010 & $-1.7108 * *$ & 5.781 \\
\hline AGE70 & -0.0840 & 0.588 & 0.0174 & 0.097 & -0.2758 & 1.446 & -0.0842 & 0.554 \\
\hline AGE80 & -0.1363 & 1.003 & $-0.3261 * *$ & 2.111 & -0.1807 & 1.074 & -0.0891 & 0.582 \\
\hline AGE90 & 0.3377 & 1.316 & 0.0218 & 0.081 & 0.1966 & 0.717 & $0.5867 * *$ & 2.179 \\
\hline ABSENT & 0.1156 & 1.445 & -0.0709 & 0.704 & $0.1722 *$ & 1.889 & $0.1848 * *$ & 2.151 \\
\hline COLLECT & 0.0986 & 1.080 & 0.1181 & 1.073 & 0.0863 & 0.812 & 0.0919 & 0.921 \\
\hline WOCO & $0.2341 * *[0.080]$ & 2.357 & $0.3528 * *[0.087$ & 2.915 & $0.2559 * *[0.078]$ & 2.187 & $0.3073 * *[0.104]$ & 2.712 \\
\hline TEAM & $0.2324 * *$ & 3.433 & $0.2471 * *$ & 2.877 & $0.2137 * *$ & 2.542 & $0.2572 * *$ & 3.124 \\
\hline PRSHARE & $0.2347 * *$ & 2.163 & $0.1978 *$ & 1.675 & $0.2116^{*}$ & 1.821 & 0.1074 & 0.947 \\
\hline MGTPRSH & $0.1589 * *$ & 2.123 & $0.2066^{* *}$ & 2.167 & 0.0969 & 1.092 & 0.1158 & 1.348 \\
\hline SIZE & $1.1327 * *$ & 4.741 & $0.4542 * *$ & 2.554 & $0.41229 * *$ & 2.054 & $0.6074 * *$ & 4.476 \\
\hline SIZESQD & -0.0662 & 1.079 & -0.0265 & 1.016 & -0.0223 & 1.190 & $-0.0373 * *$ & 3.287 \\
\hline TECH & $0.1415^{*}$ & 1.940 & $0.2886^{* *}$ & 3.208 & $0.2090 * *$ & 2.453 & 0.0355 & 0.408 \\
\hline RESEARCH & 0.0378 & 0.448 & 0.1139 & 1.206 & $0.1538 *$ & 1.724 & -0.0552 & 0.593 \\
\hline STRUC & $-0.1501^{*}$ & 1.745 & -0.1181 & 1.163 & -0.1191 & 1.219 & -0.1067 & 1.145 \\
\hline GMBHKG & 0.0670 & 0.750 & 0.0911 & 0.897 & 0.0327 & 0.328 & 0.0396 & 0.413 \\
\hline $\mathrm{AG}$ & $0.4301 *$ & 1.736 & 0.2965 & 1.276 & 0.3521 & 1.593 & 0.0268 & 0.140 \\
\hline TRAIN & $0.4582 * *$ & 6.523 & $0.1807^{*}$ & 1.899 & $0.4275^{* *}$ & 4.630 & $0.5014 * *$ & 5.707 \\
\hline BLUECOL & $0.5066^{* *}$ & 2.242 & $0.8694 * *$ & 3.206 & $0.5876^{* *}$ & 2.090 & 0.11156 & 0.454 \\
\hline WOMEN & $-0.5270 * *$ & 2.475 & $-0.5863 * *$ & 2.399 & -0.2066 & 0.850 & -0.0938 & 0.408 \\
\hline REMARKET & 0.0828 & 0.885 & -0.1374 & 1.149 & $0.2003 *$ & 1.887 & $0.1737 *$ & 1.669 \\
\hline CONC & 0.0079 & 0.606 & -0.0093 & 0.610 & 0.0098 & 0.643 & 0.0119 & 0.880 \\
\hline CONCSQD & -0.0002 & 1.066 & 0.0001 & 0.371 & -0.0001 & 0.698 & -0.0002 & 0.891 \\
\hline PR & 0.1010 & 1.248 & 0.0831 & 0.822 & 0.0335 & 0.352 & 0.1083 & 1.153 \\
\hline 1994 & $-0.5761^{* *}$ & 7.506 & & & & & & \\
\hline 1995 & $-0.3387 * *$ & 4.094 & -0.0568 & 0.165 & 0.1501 & 1.804 & $0.2621 * *$ & 3.076 \\
\hline 1996 & $-0.6520 * *$ & 7.741 & 0.0694 & 0.736 & -0.1323 & 1.455 & -0.0207 & 0.241 \\
\hline$\rho$ & $0.3915^{* *}$ & 7.337 & $0.3057 * *$ & 3.846 & $0.3555^{* *}$ & 4.895 & $0.3124 * *$ & 4.279 \\
\hline Industry dummies & \multicolumn{2}{|c|}{ Included } & \multicolumn{2}{|c|}{ Included } & \multicolumn{2}{|c|}{ Included } & \multicolumn{2}{|c|}{ Included } \\
\hline Number of firms & \multicolumn{2}{|c|}{985} & \multicolumn{2}{|c|}{838} & \multicolumn{2}{|c|}{838} & \multicolumn{2}{|c|}{838} \\
\hline Number of observations & \multicolumn{2}{|c|}{2911} & \multicolumn{2}{|c|}{1978} & \multicolumn{2}{|c|}{1978} & \multicolumn{2}{|l|}{1978} \\
\hline Percent correct predictions & \multicolumn{2}{|c|}{67.71} & \multicolumn{2}{|c|}{77.91} & \multicolumn{2}{|c|}{72.85} & \multicolumn{2}{|l|}{70.98} \\
\hline McFadden $\mathrm{R}^{2}$ & \multicolumn{2}{|c|}{0.171} & \multicolumn{2}{|c|}{0.137} & \multicolumn{2}{|c|}{0.126} & \multicolumn{2}{|l|}{0.126} \\
\hline
\end{tabular}


Table 2 continued

\begin{tabular}{|c|c|c|c|c|c|c|c|c|}
\hline \multirow[b]{2}{*}{ Exogenous Variables } & \multicolumn{2}{|c|}{ ENV4 } & \multicolumn{2}{|c|}{ ENVPROD } & \multicolumn{2}{|c|}{ INNOV1 } & \multicolumn{2}{|c|}{ INNOV2 } \\
\hline & $\hat{\beta}$ & $|t|$ & $\hat{\beta}$ & $|t|$ & $\hat{\beta}$ & $|t|$ & $\hat{\beta}$ & $|t|$ \\
\hline Constant & $-2.3500 * *$ & 5.666 & $-2.1481 * *$ & 4.968 & 0.1462 & 0.473 & $-1.4742 * *$ & 5.145 \\
\hline AGE70 & -0.1497 & 0.701 & -0.0077 & 0.032 & 0.1039 & 0.550 & -0.0355 & 0.223 \\
\hline AGE80 & -0.1312 & 0.614 & -0.2840 & 1.098 & -0.2299 & 1.281 & 0.1499 & 1.055 \\
\hline AGE90 & 0.4318 & 1.498 & 0.5477 & 1.388 & -0.0076 & 0.024 & -0.2720 & 0.968 \\
\hline ABSENT & 0.1103 & 0.968 & 0.1432 & 1.125 & $0.2805^{* *}$ & 3.076 & 0.0356 & 0.412 \\
\hline COLLECT & 0.1472 & 1.167 & $-0.2730^{* *}$ & 2.042 & -0.0700 & 0.658 & -0.0776 & 0.785 \\
\hline WOCO & $0.4081 * *[0.070]$ & 2.784 & $0.1489[0.001]$ & 1.003 & $0.2099 *[0.084]$ & 1.869 & $0.0549[0.012]$ & 0.514 \\
\hline TEAM & $0.3225 * *$ & 3.211 & $0.2528 * *$ & 2.252 & 0.0990 & 1.298 & $0.3489 * *$ & 4.483 \\
\hline PRSHARE & $0.2571^{*}$ & 1.770 & -0.0430 & 0.270 & $0.2898 * *$ & 2.342 & $0.2199 * *$ & 2.095 \\
\hline MGTPRSH & $0.3895 * *$ & 3.369 & 0.0956 & 0.796 & 0.0641 & 0.721 & 0.0494 & 0.561 \\
\hline SIZE & $0.9232 * *$ & 2.268 & $0.5092 * *$ & 2.150 & $0.6820 * *$ & 3.013 & $0.6363 * *$ & 3.991 \\
\hline SIZESQD & -0.0552 & 0.367 & -0.0261 & 1.065 & $-0.0496 * *$ & 2.366 & $-0.0426 * *$ & 3.285 \\
\hline TECH & 0.1203 & 1.068 & $0.2777 * *$ & 2.387 & $0.1540^{*}$ & 1.747 & $0.2388 * *$ & 2.803 \\
\hline RESEARCH & $0.3144 * *$ & 2.932 & $0.2758 * *$ & 2.401 & $0.4009 * *$ & 4.329 & $0.2436^{* *}$ & 2.870 \\
\hline STRUC & -0.1825 & 1.460 & 0.0472 & 0.363 & -0.1529 & 1.608 & $-0.1830 * *$ & 2.009 \\
\hline GMBHKG & 0.0388 & 0.322 & 0.1673 & 1.178 & $0.2040^{*}$ & 1.924 & 0.0057 & 0.057 \\
\hline $\mathrm{AG}$ & -0.1109 & 0.445 & 0.4351 & 1.254 & 0.1026 & 0.357 & -0.0633 & 0.261 \\
\hline TRAIN & & & 0.1159 & 0.910 & $0.2105 * *$ & 2.477 & $0.1947 * *$ & 2.367 \\
\hline BLUECOL & 0.0751 & 0.218 & $-0.9002 * *$ & 2.503 & $-0.7639 * *$ & 2.798 & 0.2642 & 1.131 \\
\hline WOMEN & -0.4200 & 1.309 & 0.3656 & 1.087 & $0.5373 * *$ & 2.330 & 0.1688 & 0.720 \\
\hline REMARKET & 0.1556 & 1.104 & -0.1766 & 1.143 & $-0.5045^{* *}$ & 4.892 & -0.0679 & 0.700 \\
\hline CONC & 0.0128 & 0.669 & 0.0005 & 0.022 & -0.0186 & 1.174 & $-0.0328 * *$ & 2.107 \\
\hline CONCSQD & -0.0001 & 0.408 & 0.0001 & 0.301 & 0.0002 & 0.728 & $0.0005 * *$ & 2.244 \\
\hline PR & -0.0579 & 0.481 & $0.2220 *$ & 1.807 & 0.0755 & 0.867 & 0.1185 & 1.357 \\
\hline 1994 & & & 0.0758 & 0.648 & $0.1858 * *$ & 2.290 & $-0.2511 * *$ & 2.988 \\
\hline 1995 & $0.3864 * *$ & 3.715 & $-0.2950 * *$ & 2.251 & 0.1010 & 1.145 & 0.1074 & 1.152 \\
\hline 1996 & $0.1844 *$ & 1.765 & -0.1261 & 0.944 & $0.2617 * *$ & 2.799 & -0.1133 & 1.228 \\
\hline$\rho$ & $0.4494 * *$ & 5.188 & $0.5275^{* *}$ & 6.283 & $0.5542 * *$ & 9.659 & $0.3621 * *$ & 5.518 \\
\hline Industry dummies & \multicolumn{2}{|c|}{ Included } & \multicolumn{2}{|c|}{ Included } & \multicolumn{2}{|c|}{ included } & \multicolumn{2}{|c|}{ Included } \\
\hline Number of firms & \multicolumn{2}{|c|}{838} & \multicolumn{2}{|c|}{984} & \multicolumn{2}{|c|}{986} & \multicolumn{2}{|c|}{986} \\
\hline Number of observations & \multicolumn{2}{|c|}{1978} & \multicolumn{2}{|c|}{2914} & \multicolumn{2}{|c|}{2916} & \multicolumn{2}{|c|}{2917} \\
\hline Percent correct predictions & \multicolumn{2}{|c|}{81.60} & \multicolumn{2}{|c|}{89.33} & \multicolumn{2}{|c|}{67.97} & \multicolumn{2}{|c|}{79.26} \\
\hline McFadden $\mathrm{R}^{2}$ & \multicolumn{2}{|c|}{0.173} & \multicolumn{2}{|c|}{0.169} & \multicolumn{2}{|c|}{0.210} & \multicolumn{2}{|c|}{0.111} \\
\hline
\end{tabular}

$*$ or $* *$ denote levels of significance at $\alpha=0.10$ or 0.05 . Marginal effects are in square brackets. 
Table 3 Random Effects Probit. Active works council (ACWOCO).

\begin{tabular}{|c|c|c|c|c|c|c|c|c|}
\hline Exogenous Variables & $\begin{array}{l}\text { ENVDUM } \\
\hat{\beta}\end{array}$ & $\begin{array}{l}\text { ENV1 } \\
\hat{\beta}\end{array}$ & $\begin{array}{l}\text { ENV2 } \\
\hat{\beta}\end{array}$ & $\begin{array}{l}\text { ENV3 } \\
\hat{\beta}\end{array}$ & $\begin{array}{l}\text { ENV4 } \\
\hat{\beta}\end{array}$ & $\begin{array}{l}\text { ENVPROD } \\
\hat{\beta}\end{array}$ & $\begin{array}{l}\text { INNOV1 } \\
\hat{\beta}\end{array}$ & $\begin{array}{l}\text { INNOV2 } \\
\hat{\beta}\end{array}$ \\
\hline \multirow[t]{3}{*}{ ACWOCO } & $0.3236 * *$ & $0.3019 * *$ & $0.6048 * *$ & $0.5321 * *$ & $0.5035 * *$ & 0.1079 & -0.1509 & 0.0698 \\
\hline & $(2.438)$ & $(2.136)$ & $(4.196)$ & $(4.075)$ & $(4.914)$ & $(0.581)$ & $(1.090)$ & $(0.524)$ \\
\hline & {$[0.127]$} & {$[0.074]$} & {$[0.184]$} & {$[0.181]$} & {$[0.123]$} & {$[0.006]$} & {$[-0.060]$} & {$[0.015]$} \\
\hline \multirow[t]{2}{*}{$\rho$} & $0.3724 * *$ & $0.3177 * *$ & $0.3113 * *$ & $0.2755^{*} *$ & 0.0432 & $0.5199 * *$ & $0.5554 * *$ & $0.3683 * *$ \\
\hline & $(6.998)$ & $(4.007)$ & $(3.810)$ & $(3.704)$ & $(0.622)$ & $(6.054)$ & $(9.652)$ & $(5.546)$ \\
\hline Number of firms & 915 & 837 & 837 & 837 & 837 & 916 & 916 & 916 \\
\hline Number of observations & 2813 & 1955 & 1955 & 1955 & 1955 & 2818 & 2818 & 2819 \\
\hline Percent correct predictions & 66.83 & 78.06 & 73.81 & 71.15 & 81.53 & 89.57 & 67.49 & 79.60 \\
\hline McFadden $\mathrm{R}^{2}$ & 0.168 & 0.137 & 0.134 & 0.125 & 0.147 & 0.170 & 0.213 & 0.114 \\
\hline
\end{tabular}

Note that all variables listed in Table 2 are included in each estimation but are suppressed to save space. T-statistics are in parentheses. ${ }^{*}$ and $* *$ denote levels of

significance at $\alpha=0.10$ and 0.05 . Marginal effects are in square brackets.

Table 4 Random Effects Probit. Works council in interaction with how employee involvement is evaluated by management.

\begin{tabular}{|c|c|c|c|c|c|c|c|c|}
\hline Exogenous Variables & $\begin{array}{l}\text { ENVDUM } \\
\hat{\beta}\end{array}$ & $\begin{array}{l}\text { ENV1 } \\
\hat{\beta}\end{array}$ & $\begin{array}{l}\text { ENV2 } \\
\hat{\beta}\end{array}$ & $\begin{array}{l}\text { ENV3 } \\
\hat{\beta}\end{array}$ & $\begin{array}{l}\text { ENV4 } \\
\hat{\beta}\end{array}$ & $\begin{array}{l}\text { ENVPROD } \\
\hat{\beta}\end{array}$ & $\begin{array}{l}\text { INNOV1 } \\
\hat{\beta}\end{array}$ & $\begin{array}{l}\text { INNOV2 } \\
\hat{\beta}\end{array}$ \\
\hline \multirow[t]{3}{*}{ WINVOLV } & $0.2445 * *$ & $0.3852 * *$ & $0.2445 * *$ & $0.3609 * *$ & $0.4371 * *$ & 0.2098 & $0.2793 * *$ & 0.0713 \\
\hline & $(2.381)$ & $(3.019)$ & $(2.064)$ & $(3.131)$ & $(2.979)$ & $(1.396)$ & $(2.406)$ & $(0.653)$ \\
\hline & {$[0.096]$} & {$[0.093]$} & {$[0.075]$} & {$[0.122]$} & {$[0.077]$} & [0.012] & {$[0.111]$} & {$[0.016]$} \\
\hline \multirow[t]{3}{*}{ WNOVOLV } & 0.1780 & 0.2207 & 0.2405 & 0.1011 & 0.1952 & -0.2629 & -0.1510 & 0.0026 \\
\hline & $(1.305)$ & $(1.534)$ & $(1.461)$ & $(0.625)$ & $(0.899)$ & $(0.989)$ & $(0.908)$ & $(0.015)$ \\
\hline & {$[0.070]$} & {$[0.053]$} & {$[0.073]$} & {$[0.034]$} & {$[0.034]$} & {$[-0.015]$} & {$[-0.060]$} & {$[0.001]$} \\
\hline \multirow[t]{2}{*}{$\rho$} & $0.3829 * *$ & $0.3148 * *$ & $0.3466 * *$ & $0.3013 * *$ & $0.4298 * *$ & $0.5221 * *$ & $0.5583 * *$ & $0.3658 * *$ \\
\hline & $(7.143)$ & $(3.829)$ & $(4.707)$ & $(4.050)$ & $(4.851)$ & $(6.106)$ & $(9.615)$ & $(5.450)$ \\
\hline Number of firms & 982 & 835 & 835 & 835 & 835 & 981 & 983 & 983 \\
\hline Number of observations & 2868 & 1937 & 1937 & 1937 & 1937 & 2871 & 2873 & 2874 \\
\hline Percent correct predictions & 67.75 & 77.90 & 73.10 & 71.35 & 81.52 & 89.17 & 68.19 & 79.33 \\
\hline McFadden $\mathrm{R}^{2}$ & 0.171 & 0.139 & 0.126 & 0.125 & 0.169 & 0.172 & 0.212 & 0.111 \\
\hline
\end{tabular}

Note that all variables listed in Table 2 are included in each estimation but are suppressed to save space. T-statistics are in parentheses. ${ }^{*}$ and $*^{* *}$ denote levels of significance of $\alpha=0.10$ and 0.05 . Marginal effects are in square brackets. 
Table 5 Random Effects Probit. Active works council in interaction with how employee involvement is evaluated by management.

\begin{tabular}{|c|c|c|c|c|c|c|c|c|}
\hline Exogenous Variables & $\begin{array}{l}\text { ENVDUM } \\
\hat{\beta}\end{array}$ & $\begin{array}{l}\text { ENV1 } \\
\hat{\beta}\end{array}$ & $\begin{array}{l}\text { ENV2 } \\
\hat{\beta}\end{array}$ & $\begin{array}{l}\text { ENV3 } \\
\hat{\beta}\end{array}$ & $\begin{array}{l}\text { ENV4 } \\
\hat{\beta}\end{array}$ & $\begin{array}{l}\text { ENVPROD } \\
\hat{\beta}\end{array}$ & $\begin{array}{l}\text { INNOV1 } \\
\hat{\beta}\end{array}$ & $\begin{array}{l}\text { INNOV2 } \\
\hat{\beta}\end{array}$ \\
\hline$\overline{A C I N V O L V}$ & $\begin{array}{l}0.4365 * * \\
(2.907) \\
{[0.172]}\end{array}$ & $\begin{array}{l}0.3557 * * \\
(2.348) \\
{[0.087]}\end{array}$ & $\begin{array}{l}0.7586 * * \\
(4.819) \\
{[0.231]}\end{array}$ & $\begin{array}{l}0.7169 * * \\
(4.909) \\
{[0.244]}\end{array}$ & $\begin{array}{l}0.6560 * * \\
(4.170) \\
{[0.119]}\end{array}$ & $\begin{array}{l}0.1446 \\
(0.751) \\
{[0.008]}\end{array}$ & $\begin{array}{c}-0.1391 \\
(0.953) \\
{[-0.055]}\end{array}$ & $\begin{array}{l}0.0945 \\
(0.664) \\
{[0.020]}\end{array}$ \\
\hline ACNOVOLV & $\begin{array}{c}-0.3132 \\
(1.066) \\
{[-0.123]}\end{array}$ & $\begin{array}{c}-0.0733 \\
(0.177) \\
{[-0.018]}\end{array}$ & $\begin{array}{c}-0.4573 \\
(1.115) \\
{[-0.139]}\end{array}$ & $\begin{array}{c}-0.8082 * * \\
(1.993) \\
{[-0.275]}\end{array}$ & $\begin{array}{c}-0.4580 \\
(1.098) \\
{[-0.083]}\end{array}$ & $\begin{array}{c}-0.2534 \\
(0.361 \\
{[-0.014]}\end{array}$ & $\begin{array}{c}-0.2200 \\
(0.594) \\
{[-0.088]}\end{array}$ & $\begin{array}{c}-0.0984 \\
(0.268) \\
{[-0.021]}\end{array}$ \\
\hline$\rho$ & $\begin{array}{l}0.3752 * * \\
(7.042)\end{array}$ & $\begin{array}{l}0.3124^{* *} \\
(3.815)\end{array}$ & $\begin{array}{l}0.3429 * * \\
(4.650)\end{array}$ & $\begin{array}{l}0.2765^{* *} \\
(3.650)\end{array}$ & $\begin{array}{l}0.4064 * * \\
(4.642)\end{array}$ & $\begin{array}{l}0.5203^{* *} \\
(6.003)\end{array}$ & $\begin{array}{l}0.5552 * * \\
(9.653)\end{array}$ & $\begin{array}{l}0.3690 * * \\
(5.554)\end{array}$ \\
\hline Number of firms & 915 & 837 & 837 & 837 & 837 & 916 & 916 & 916 \\
\hline Number of observations & 2813 & 1955 & 1955 & 1955 & 1955 & 2818 & 2818 & 2819 \\
\hline Percent correct predictions & 66.97 & 77.85 & 73.76 & 71.61 & 81.74 & 89.57 & 67.46 & 79.60 \\
\hline McFadden $\mathrm{R}^{2}$ & 0.169 & 0.137 & 0.138 & 0.132 & 0.172 & 0.170 & 0.213 & 0.116 \\
\hline
\end{tabular}

Note that all variables listed in Table 2 are included in each estimation but are suppressed to save space. T-statistics are in parentheses. * and ** denote levels of significance of $\alpha=0.10$ and 0.05 . Marginal effects are in square brackets. 


\section{Endnotes.}

${ }^{1}$ See esp. Vanek, 1970 (pp. 268-270 and pp. 276-279) and 1971 (pp. 33-35).

${ }^{2}$ As Müller-Jentsch (1995, p. 60) puts it, 'For example, the council can hold up decisions on staff movements where it has veto rights, or it can withhold consent on overtime where it has co-determination rights, in order to obtain concessions on other issues.'

${ }^{3}$ A condition is that the number of preferences be greater than the number of working conditions. The analysis is based on a Slutsky equation for quality changes, in which the source of the discrepancy is decomposed into two components. First, an individual employee's labor supply may be affected by a compensated change in working conditions; and second, the aggregation over workers of labor supply and of preferences for working conditions obey different rules, which may lead to an aggregation bias; see Dreze (1976).

${ }^{4}$ As Vanek (1970) puts it, “For local residents, pollution reduction has properties of public goods: each worker may gain utility from these benefits, but this utility is not gained at the expense of any other worker's ability to likewise 'consume' this satisfaction, nor would it be easy to exclude workers from the benefits."

${ }^{5}$ For the United States Bertrand (1999) presents empirical evidence that firms that are subject to more product market competition are more likely to renege on implicit contracts. Competition induces financial distress. Therefore, it reduces the employer's gains from future trustful relationships.

${ }^{6}$ There are at least three reasons why under certain circumstances a positive impact of environmental protection on firm performance can be expected. First, many environmental investments have the effect of reducing materials waste or other wastage allowances. Second, in the longer run, such investments might increase productivity further, as they spur complementary investments or increases in skill, or possibly induce a shift to higher quality products. As Porter and van der Linde (1995) argue, environmental regulation can trigger innovations whose value can outweigh the costs of adhering to the regulations. Third, firms operating in regional markets could be interested in environmental investment because they care about their community reputation. Bargaining by works councils to obtain greater environmental protection can be similar to the effect of greater exogenous regulation; and thus responses such as those outlined by Porter and van der Linde could also apply to this case. This assumption is not required for the analysis, but helps to clarify the interpretation of some of the results.

${ }^{7}$ An equivalent tradeoff may be present for the disutility of worker effort.

${ }^{8}$ Note that the variables ENV1-4 are only available from wave 2-4. 
CESifo Working Paper Series

(for full list see www.cesifo.de)

715 Giorgio Brunello, Maria Laura Parisi, and Daniela Sonedda, Labor Taxes and Wages: Evidence from Italy, May 2002

716 Marta Aloi and Huw Dixon, Entry Dynamics, Capacity Utilisation and Productivity in a Dynamic Open Economy, May 2002

717 Paolo M. Panteghini, Asymmetric Taxation under Incremental and Sequential Investment, May 2002

718 Ben J. Heijdra, Christian Keuschnigg, and Wilhelm Kohler, Eastern Enlargement of the EU: Jobs, Investment and Welfare in Present Member Countries, May 2002

719 Tapio Palokangas, The Political Economy of Collective Bargaining, May 2002

720 Gilles Saint-Paul, Some Evolutionary Foundations for Price Level Rigidity, May 2002

721 Giorgio Brunello and Daniela Sonedda, Labor Tax Progressivity, Wage Determination, and the Relative Wage Effect, May 2002

722 Eric van Damme, The Dutch UMTS-Auction, May 2002

723 Paolo M. Panteghini, Endogenous Timing and the Taxation of Discrete Investment Choices, May 2002

724 Achim Wambach, Collusion in Beauty Contests, May 2002

725 Dominique Demougin and Claude Fluet, Preponderance of Evidence, May 2002

726 Gilles Saint-Paul, Growth Effects of Non Proprietary Innovation, May 2002

727 Subir Bose, Gerhard O. Orosel, and Lise Vesterlund, Optimal Pricing and Endogenous Herding, May 2002

728 Erik Leertouwer and Jakob de Haan, How to Use Indicators for 'Corporatism' in Empirical Applications, May 2002

729 Matthias Wrede, Small States, Large Unitary States and Federations, May 2002

730 Christian Schultz, Transparency and Tacit Collusion in a Differentiated Market, May 2002

731 Volker Grossmann, Income Inequality, Voting Over the Size of Public Consumption, and Growth, May 2002

$732 \mathrm{Yu}-\mathrm{Fu}$ Chen and Michael Funke, Working Time and Employment under Uncertainty, May 2002 
733 Kjell Erik Lommerud, Odd Rune Straume, and Lars Sørgard, Downstream Merger with Oligopolistic Input Suppliers, May 2002

734 Saku Aura, Does the Balance of Power Within a Family Matter? The Case of the Retirement Equity Act, May 2002

735 Sandro Brusco and Fausto Panunzi, Reallocation of Corporate Resources and Managerial Incentives in Internal Capital Markets, May 2002

736 Stefan Napel and Mika Widgrén, Strategic Power Revisited, May 2002

737 Martin W. Cripps, Godfrey Keller, and Sven Rady, Strategic Experimentation: The Case of Poisson Bandits, May 2002

738 Pierre André Chiappori and Bernard Salanié, Testing Contract Theory: A Survey of Some Recent Work, June 2002

739 Robert J. Gary-Bobo and Sophie Larribeau, A Structural Econometric Model of Price Discrimination in the Mortgage Lending Industry, June 2002

740 Laurent Linnemer, When Backward Integration by a Dominant Firm Improves Welfare, June 2002

741 Gebhard Kirchgässner and Friedrich Schneider, On the Political Economy of Environmental Policy, June 2002

742 Christian Keuschnigg and Soren Bo Nielsen, Start-ups, Venture Capitalits, and the Capital Gains Tax, June 2002

743 Robert Fenge, Silke Uebelmesser, and Martin Werding, Second-best Properties of Implicit Social Security Taxes: Theory and Evidence, June 2002

744 Wendell Fleming and Jerome Stein, Stochastic Optimal Control, International Finance and Debt, June 2002

745 Gene M. Grossman, The Distribution of Talent and the Pattern and Consequences of International Trade, June 2002

746 Oleksiy Ivaschenko, Growth and Inequality: Evidence from Transitional Economies, June 2002

747 Burkhard Heer, Should Unemployment Benefits be Related to Previous Earnings?, July 2002

748 Bas van Aarle, Giovanni Di Bartolomeo, Jacob Engwerda, and Joseph Plasmans, Staying Together or Breaking Apart: Policy-makers' Endogenous Coalitions Formation in the European Economic and Monetary Union, July 2002

749 Hans Gersbach, Democratic Mechanisms: Double Majority Rules and Flexible Agenda Costs, July 2002 
750 Bruno S. Frey and Stephan Meier, Pro-Social Behavior, Reciprocity or Both?, July 2002

751 Jonas Agell and Helge Bennmarker, Wage Policy and Endogenous Wage Rigidity: A Representative View From the Inside, July 2002

752 Edward Castronova, On Virtual Economies, July 2002

753 Rebecca M. Blank, U.S. Welfare Reform: What's Relevant for Europe?, July 2002

754 Ruslan Lukach and Joseph Plasmans, Measuring Knowledge Spillovers Using Patent Citations: Evidence from the Belgian Firm's Data, July 2002

755 Aaron Tornell and Frank Westermann, Boom-Bust Cycles in Middle Income Countries: Facts and Explanation, July 2002

756 Jan K. Brueckner, Internalization of Airport Congestion: A Network Analysis, July 2002

757 Lawrence M. Kahn, The Impact of Wage-Setting Institutions on the Incidence of Public Employment in the OECD: 1960-98, July 2002

758 Sijbren Cnossen, Tax Policy in the European Union, August 2002

759 Chandima Mendis, External Shocks and Banking Crises in Developing Countries: Does the Exchange Rate Regime Matter?, August 2002

760 Bruno S. Frey and Lars P. Feld, Deterrence and Morale in Taxation: An Empirical Analysis, August 2002

761 Lars Calmfors and Åsa Johansson, Nominal Wage Flexibility, Wage Indexation and Monetary Union, August 2002

762 Alexander R. W. Robson and Stergios Skaperdas, Costly Enforcement of Property Rights and the Coase Theorem, August 2002

763 Horst Raff, Preferential Trade Agreements and Tax Competition for Foreign Direct Investment, August 2002

764 Alex Cukierman and V. Anton Muscatelli, Do Central Banks have Precautionary Demands for Expansions and for Price Stability? - Theory and Evidence, August 2002

765 Giovanni Peri, Knowledge Flows and Knowledge Externalities, August 2002

766 Daniel Friedman and Nirvikar Singh, Equilibrium Vengeance, August 2002

767 Sam Bucovetsky and Michael Smart, The Efficiency Consequences of Local Revenue Equalization: Tax Competition and Tax Distortions, August 2002

768 Tapio Palokangas, International Labour Market Regulation and Economic Growth with Creative Destruction, August 2002

769 Rudi Dornbusch, The New International Architecture, September 2002 
770 Hans-Werner Sinn, Weber's Law and the Biological Evolution of Risk Preferences: The Selective Dominance of the Logarithmic Utility Function, September 2002

771 Thomas Mayer, The Macroeconomic Loss Function: A Critical Note, September 2002

772 Seppo Honkapohja and Kaushik Mitra, Learning Stability in Economies with Heterogenous Agents, September 2002

773 David Laidler, Inflation Targets Versus International Monetary Integration - A Canadian Perspective, September 2002

774 Morten I. Lau, Panu Poutvaara, and Andreas Wagener, The Dynamic Cost of the Draft, September 2002

775 Steven Brakman, Harry Garretsen, and Charles van Marrewijk, Locational Competition and Agglomeration: The Role of Government Spending, September 2002

776 Anke S. Kessler and Christoph Lülfesmann, The Theory of Human Capital Revisited: On the Interaction of General and Specific Investments, September 2002

777 Kjell Erik Lommerud, Frode Meland and Lars Sørgard, Unionized Oligopoly, Trade Liberalization and Location Choice, September 2002

778 Antonio Merlo and François Ortalo-Magné, Bargaining over Residential Real Estate: Evidence from England, September 2002

$779 \mathrm{Yu}-\mathrm{Fu}$ Chen and Michael Funke, Exchange Rate Uncertainty and Labour Market Adjustment under Fixed and Flexible Exchange Rates, September 2002

780 Michael S. Michael, International Migration, Income Taxes and Transfers: A Welfare Analysis, September 2002

781 Clemens Fuest and Alfons Weichenrieder, Tax Competition and Profit Shifting: On the Relationship between Personal and Corporate Tax Rates, October 2002

782 Jan Bouckaert and Hans Degryse, Softening Competition by Enhancing Entry: An Example from the Banking Industry, October 2002

783 Johann K. Brunner and Susanne Pech, Adverse Selection in the Annuity Market with Sequential and Simultaneous Insurance Demand, October 2002

784 Gregory D. Hess and Eduard Pelz, The Economic Welfare Cost of Conflict: An Empirical Assessment, October 2002

785 Jan Erik Askildsen, Uwe Jirjahn, and Stephen C. Smith, Works Councils and Environmental Investment: Theory and Evidence from German Panel Data, October 2002 